\title{
20. Patent Institution, Innovation and Economic Growth in China
}

Haiyang Zhang

\section{Introduction}

The patent institution is regarded as an effective way to stimulate innovation, facilitate technological dissemination, promote trade and enhance competitiveness (Idris 2003). However, by granting exclusive property rights, the patent institution creates a monopoly which in itself results in the loss of social welfare by impeding the use and development of the patented technologies by others (Drahos 1995, 1999). Therefore, the overall role of the patent institution in promoting economic development, especially for developing countries characterised by a generally low technology level, is rather ambiguous, and depends on facts that vary from case to case.

Economic reform and development in China have been accompanied by the evolution of the Chinese patent institution. Moreover, China now is in a critical transition period from a manufacturing-centric to an innovation-based economy. The patent institution is seen as playing an increasingly important role in China's technological and economic development. This chapter provides some insights into whether and how the Chinese patent institution has stimulated research and development, influenced technology transfer from advanced economies and promoted economic growth in China.

Section two reviews the basic economic theories behind the patent institution, followed by the arguments for and against it in section three. The fourth section introduces the development of China's patent institution, while section five discusses what we can learn from past studies of the roles of the patent institution in China's economic development. Section six concludes by summarising policy suggestions for designing and improving the patent institution for China. 


\section{The core economic theories behind the patent institution}

Like knowledge or information, a new invention costs human and financial resources to create. However, it has characteristics of a public good: non-rival and non-excludable in consumption. The non-rival character of knowledge implies that the amount of knowledge available to any user does not decrease when others use it, while the non-excludable character of knowledge is in the sense that once it is produced, others cannot be stopped from benefiting from it, and as a result everyone can freely use it unless the state creates a legal exclusive right. Although an invention sometimes can be excludable by keeping it secret, such as the recipe of Coca Cola, there is a risk that such secrets may be easily discovered by reverse engineering or through other means.

A patent for an invention is a property right granted by a government to the patent owner or owners to exclusively make, use and sell that invention for a certain period, and as an exchange condition, it is required to disclose the invention to the public. Thus, acquiring a patent for a particular creation of knowledge is an example of making a non-rival good excludable. By granting the exclusive right on a patented invention, the patentee(s) can charge a higher price or enjoy a lower marginal cost while excluding others from doing so.

Since newly invented knowledge has the characteristics of non-excludability and non-rivalry, the provision of such goods will be below the socially desired level due to the free-rider problem. That is, unless there are some incentives granted by the government, entrepreneurs who expect profit from research and development (R\&D) may not be willing to take on the risks and costs of such activities since any rewards from doing so may dissipate due to imitation. In such a context, it is traditionally argued that perfect competition in the market of knowledge-based products does not allow innovators to recover their innovation costs such as R\&D investment (Arrow 1962). It is called innovation market failure - summarised in Martin and Scott (2000) and Colombo and Delmastro (2002) — which mainly refers to the phenomenon of underinvestment in innovation from the social standpoint. The patent institution is a social institution intended to alleviate the negative impact of innovation market failure by granting patent owners exclusive rights to make, use and sell their inventions for a certain period.

The exclusive rights given by the Chinese Patent Law may, however, cause monopolies, which are another sort of market failure. Basic economics indicates that a monopoly harms social welfare at least from the static point of view. Although not all patents can cause a monopoly, the market power associated with patents can impose social costs even as it encourages invention and commercialisation. Accordingly, societies limit the power of patent grants not 
only in duration and scope, but also in disclosure requirements. Some scholars argue that there is no general market failure for innovations as, in most industries, the cost of invention is low: or just being first in the market confers a durable competitive advantage (Moir 2008; Posner 2012). Therefore, the core economics of patents, also applied to some other intellectual property rights, is that it is an institution facing the inherent trade-off between encouraging innovation and suffering the consequences of potential monopoly.

\section{Arguments for and against the patent institution}

As modern economic growth depends more and more heavily on technological progress, the role of the patent institution attracts more and more attention and debate. Arguments for and against patents continue. At the time when the patent institution was being established, those who were in favour of it believed it could stimulate inventions and creations (Smith 1776; Bentham 1839), whereas some thought the patent institution was unnecessary because inventions were based on the inspiration of inventors and had little to do with incentives, and even when some inventions were induced by profit incentives, the profits obtained through selling first in the market were large enough to compensate for invention costs (Taussig 1915; Pigou 1920).

Today, it is commonly recognised that the patent is a necessary and valid policy instrument to overcome market failure caused by the non-rival and nonexcludable features of knowledge, and to encourage investment in R\&D and thus promote the production of knowledge and innovations. Debate is more heated about the optimal design of the patent institution: whether the patent institution has led to an excessive monopoly distortion due to excessively long and wide patent protection, and hence a slowdown in the pace of technological progress (Boldrin and Levine 2002; Heller and Eisenberg 1998; Merges and Nelson 1994).

This debate has been intensified and complicated by the current context of economic globalisation. The Agreement on Trade-Related Aspects of Intellectual Property Rights (TRIPS) was reached during the Uruguay Round (1986-94) of negotiations on the reform of the world trading system, with a view to reducing or eliminating tensions due to cross-country differences in the treatment of intellectual property rights (IPRs). The TRIPS Agreement imposes on all member economies 'minimum' standards for the protection of intellectual property. For example, the term of patent protection is at least 20 years counted from the filing date, and the patentable subject matter covers almost all fields of technology including pharmaceuticals, agriculture, chemicals, food and microorganisms, where most developing countries used to provide no or little patent protection. Although the countries on the United Nation's list of least- 
developed countries may delay implementation of action of TRIPS in respect of pharmaceutical products until 1 January 2016, extended by the Doha Declaration, the standard on intellectual property (IP) protection required by TRIPS is still rather high for most developing countries.

In such a context, some argue strongly that IPRs including patents are necessary to stimulate economic growth, which, in turn, contributes to poverty reduction. By stimulating invention and the development of new technologies, patents will increase agricultural and industrial production, promote domestic and foreign investment in technology R\&D, facilitate technology transfer and improve the availability of medicines necessary to combat disease. Others argue the opposite: that patents do little to stimulate invention in developing countries, because the necessary human and technical capacities are often absent. Patents are ineffective at stimulating research to benefit poor people because they will not be able to afford to buy the newly developed products at high prices. Patents limit the option of technological learning through imitation and allow foreign firms to drive out domestic competition by obtaining patent protection and to service the market through imports rather than domestic manufacture. Moreover, they increase the costs of essential medicines and agricultural inputs, affecting poor people and farmers particularly badly (UK Commission on IPR 2002).

Thus, the relationship between patents and economic development is complex. Moreover, there seems to be a gap between the economic research and patent institution design, especially in the case of China, which might have been caused by a lack of communication between economic researchers and the patent community, whose members are mainly scientists, engineers and legal professionals.

\section{The patent institution in China}

China promulgated its first modern Chinese Patent Law on 12 March 1984, which came into effect on 1 April 1985. Until now, the law has been amended three times. The first revision, undertaken in 1992, extended the patent length from 15 to 20 years for invention patents and from five to 10 years for patents 
of utility model and industrial design; ${ }^{1}$ expanded patent protection scope to include pharmaceuticals, food and drinks, and chemical products; and adopted some other measures to strengthen patent protection.

The second revision, which was completed in September 2000, eliminated the provisions under the old law that prevented state-owned enterprises from trading their patents in technology markets, introduced new provisions designed to make it more rewarding for employees to innovate, and amended some provisions that were not in line with the TRIPS Agreement, such as extending patent protection to offering for sale patented products. Since these two revisions, the Chinese Patent Law has been pretty much in line with the international standard.

In 2008, the Chinese Patent Law was revised for the third time. The main points of the third revision include: enhancing the threshold of patentability by changing the criteria of novelty from relative novelty to absolute noveltyone of the three factors (novelty, inventiveness and industrial applicability) of patentability in China; providing regulations on the protection of genetic resources; improving industrial design systems; improving the confidentiality examination system for applications to a foreign country; invalidating the designation of foreign-related patent agencies; increasing the responsibility of the State Intellectual Property Office (SIPO) for the distribution of patent information; endowing right holders of industrial design with the right to offer to sell, introducing pre-litigation preservation measures, and including the cost to the right holder incurred for stopping the infringing act to the calculation of damage compensation; codifying the prior art defence; allowing parallel imports; providing exceptions for drug and medical apparatus experimentation; and improving the compulsory licence system.

As we can see from the past three revisions, the Chinese Patent Law has been further strengthened step by step in a pro-patent direction. Moreover, since the mid 2000s, the Chinese Government has launched a coordinated phalanx of laws, policies and initiatives - all aimed at aggressively increasing China's capacity for

1 According to the Chinese Patent Law, there are three types of patents: invention, utility-model and design patents. 'Invention' in the Chinese Patent Law means any new technical solution relating to a product, a process or improvement thereof. 'Utility model' in the Chinese Patent Law means any new technical solution relating to the shape, the structure or their combination in a product, which is fit for practical use. 'Design' in the Chinese Patent Law means any new design of the shape, the pattern or their combination of the colour with shape or pattern, of a product, which creates an aesthetic feeling and is fit for industrial application. In most countries, however, patents refer only to the invention patents in the sense of the Chinese Patent Law. For example, the United States does not have a utility-model system, and its utility patents are virtually equivalent to invention patents in the Chinese Patent Law. Some other countries do not treat utility models and designs as patents but rather as independent types of intellectual property rights. According to the Chinese Patent Law, only invention patent applications are required for substantive examination, while utility models and designs only require preliminary examination. 
innovation. In 2006, the Government announced its 15-year 'Medium-to-LongTerm Plan for Scientific and Technological Development' (hereinafter the 15Year Plan). The 15-Year Plan included policies and standards aimed at increasing indigenous IP development before 2020, including a series of quantitative targets for development. Another key aspect of the plan was the development of 16 mega-projects focusing on key technological fields. The 15-Year Plan has since been supplemented with other policy statements and objectives-all recognising the importance of establishing and expanding the community of stakeholders in a strong IP regime. Such policy statements encourage IP transfer and alliances among companies, universities and research institutes, in order to catch up with and leapfrog into positions of leadership in several technological areas such as clean energy, electric vehicles and computing technology.

In June 2008, the Outline of the National Intellectual Property Strategy (hereinafter the 2008 Strategy) was promulgated for the purpose of improving China's capacity to create, utilise, protect and administer intellectual property, making China an innovative country and attaining the goal of building a moderately prosperous society in all respects. The 2008 Strategy emphasised the importance of creating and utilising intellectual property. More concretely, the 2008 strategy sought to make IP creation and use ubiquitous in the research and innovation activities of companies and government bodies. For example, the strategy encouraged companies to incorporate IP into their technical standards and encouraged universities to commercialise their IP.

In the more recent National Patent Development Strategy of 2010, the Government was even more assertive about benchmarks for future performance. A few of the highlights include:

- by 2015 , the number of patent filings will reach two million, which will quadruple the number filed in 2010

- by 2015, China will rank in the top two countries for the number of invention patents granted to domestic applicants

- by 2020, a quadrupling of the number of invention patents per capita and the quantity of Chinese-origin patent applications filed abroad.

In order to achieve these objectives, the Chinese Central Government, local governments, as well as universities and companies have promulgated generous incentives for the creation of IP. In universities, academic staff who do so are more likely to win tenure and promotion. Workers and students who file patents not only are entitled to prizes, but also are more likely to earn a hukou (residence permit) to live in a desirable city. For some patents, the Government pays cash bonuses; for others, it covers the substantial cost of filing. Corporate income tax can be cut from 25 per cent to 15 per cent for firms which file many patents. They are also more likely to win lucrative government contracts. 
Many companies therefore offer incentives to their employees to come up with patentable ideas. Huawei, a telecommunications equipment manufacturer that seeks both government contracts and global recognition, pays patent-related bonuses of RMB10 000-100 000 (\$1500-15 000) for inventions and creations. In addition to the above incentives, many local governments offer subsidies for the cost of filing a patent, and some provide better housing as an incentive.

Under such measures, the number of patent applications and grants has increased rapidly. Figure 20.1 shows the number of annual patent applications and grants increasing from 1985 to 2012; both patent applications and grants increased more rapidly since 2000, with an average rate of increase of more than 25 per cent. In 2011, China received 526412 applications for (invention) patents, for the first time overtaking the United States to become the largest recipient of patent applications in the world.

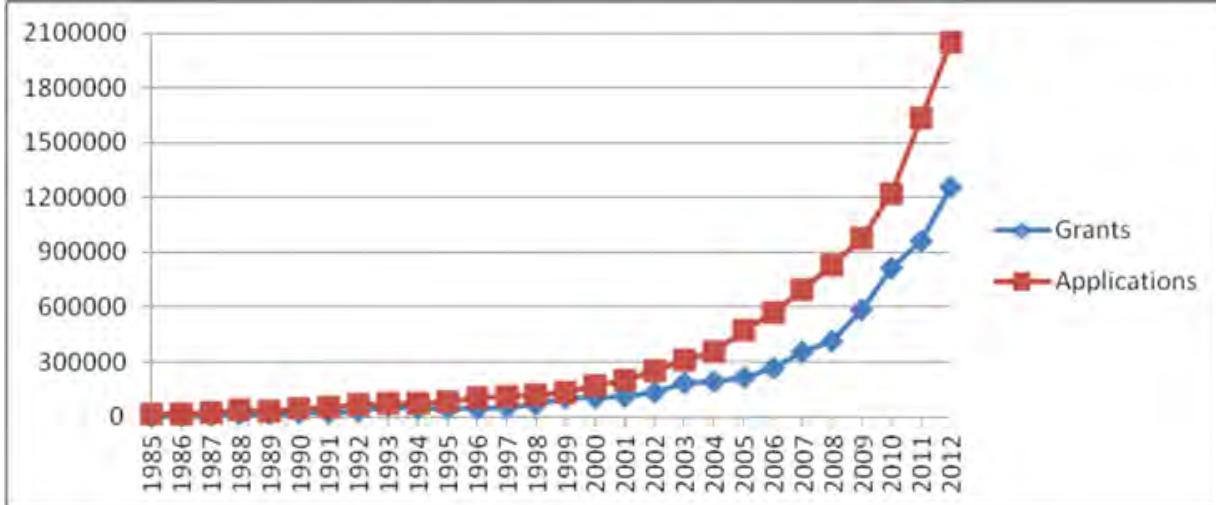

Figure 20.1 Annual Number of Patent Applications Filed and Granted at the Chinese Patent Office, 1985-2012

We can, however, see some different growth patterns if we distinguish the patent applications and grants by their types (invention, utility model and design). Figures 20.2 and 20.3 compare the patterns of three types of patents in application and grant. In Figure 20.2, we see that the three types of patent applications have been growing almost together. However, in Figure 20.3 the number of invention patents granted has been growing much more slowly than their applications in Figure 20.2, indicating a higher percentage of invention patent applications were rejected. Therefore, it is more appropriate to use the number of patent grants than patent applications to describe innovation output. 


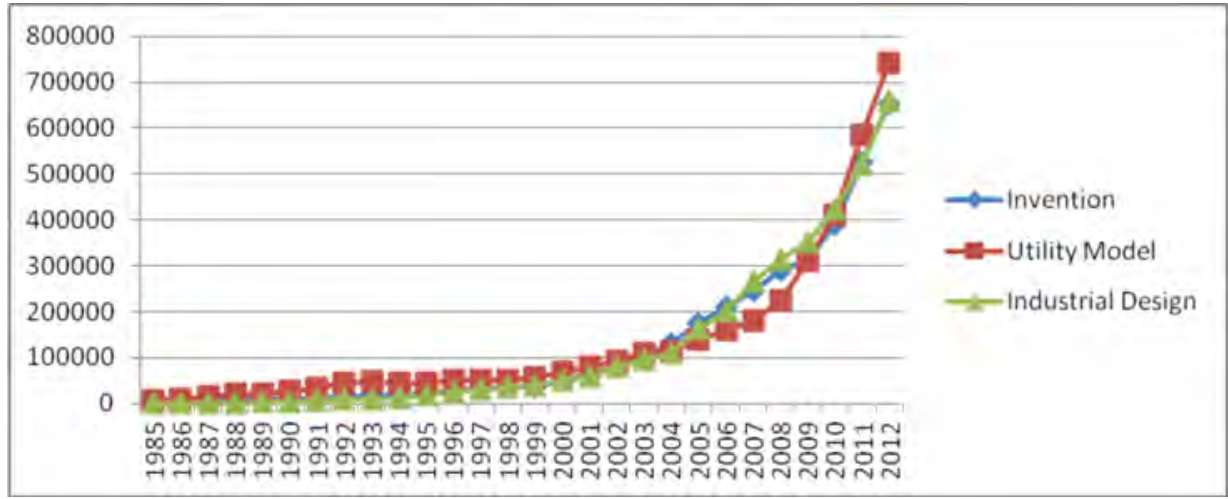

Figure 20.2 Three Types of Patent Application in China, 1985-2012

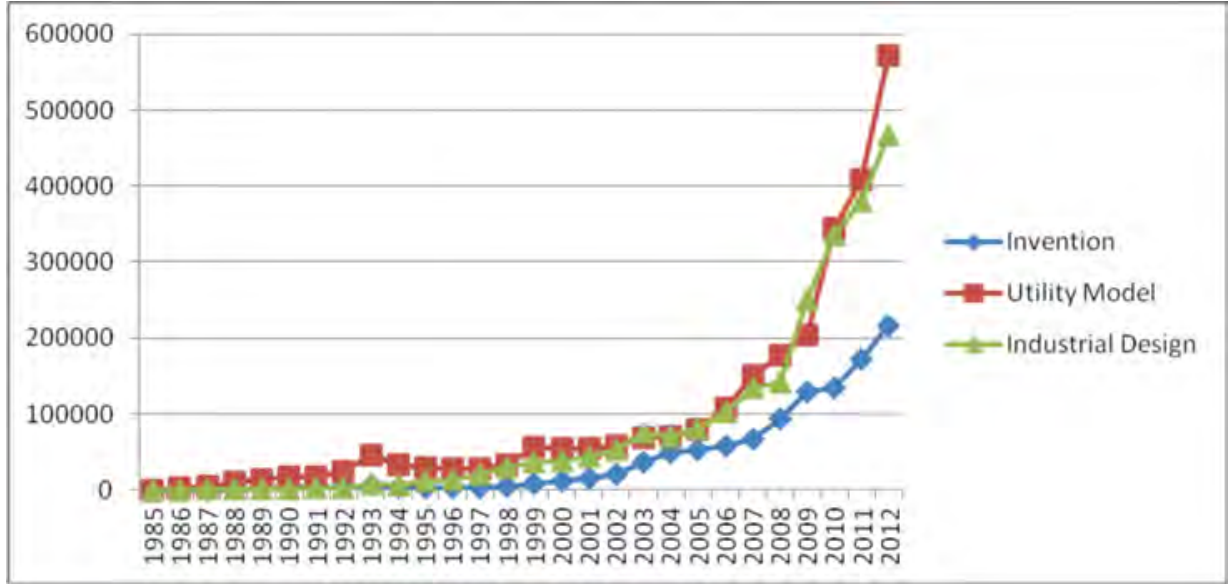

Figure 20.3 Three Types of Patent Grant in China, 1985-2012

If we compare the patents granted according to their types and origins in Figures 20.4, 20.5 and 20.6, we find that foreigners are more interested in obtaining invention patents than the other two types of patents in China. We also notice that in Figure 20.4, after the GFC in 2008, there was a clear drop in patent grants to foreigners. These comparisons carry two important messages: first, foreigners attach greater importance to invention patents in China than the other two types of patents. Second, foreign patent applicants seem more likely to be affected by the world economic situation than China's domestic patent applicants. 


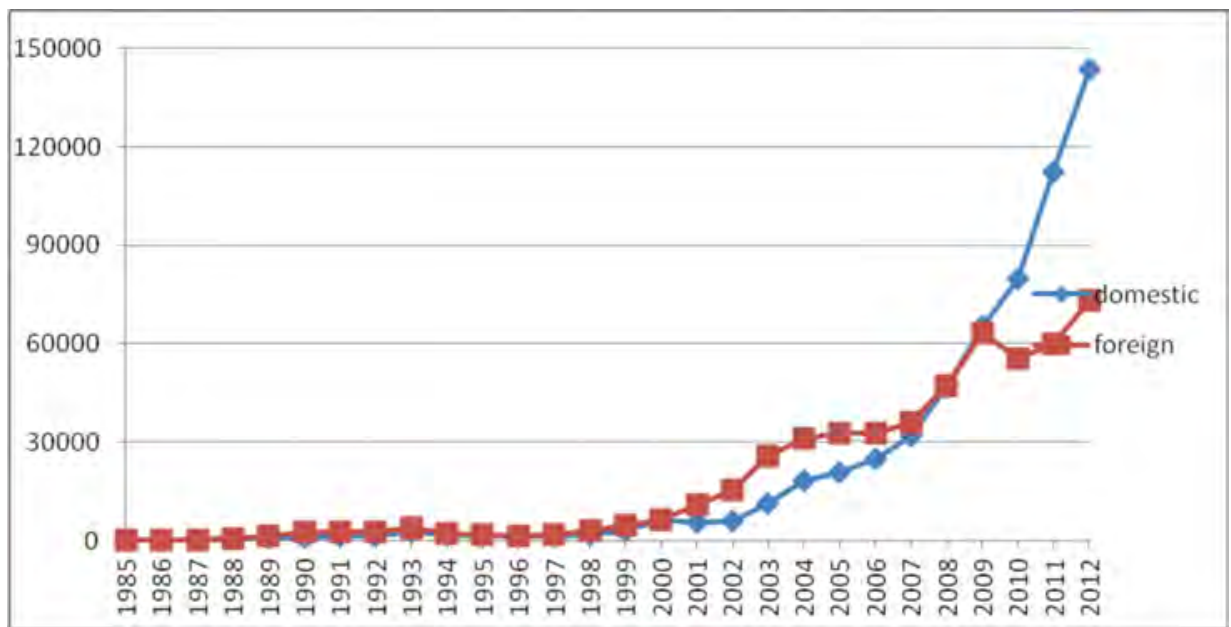

Figure 20.4 Invention Patents Granted Annually to Domestic and Foreign Entities, 1985-2012

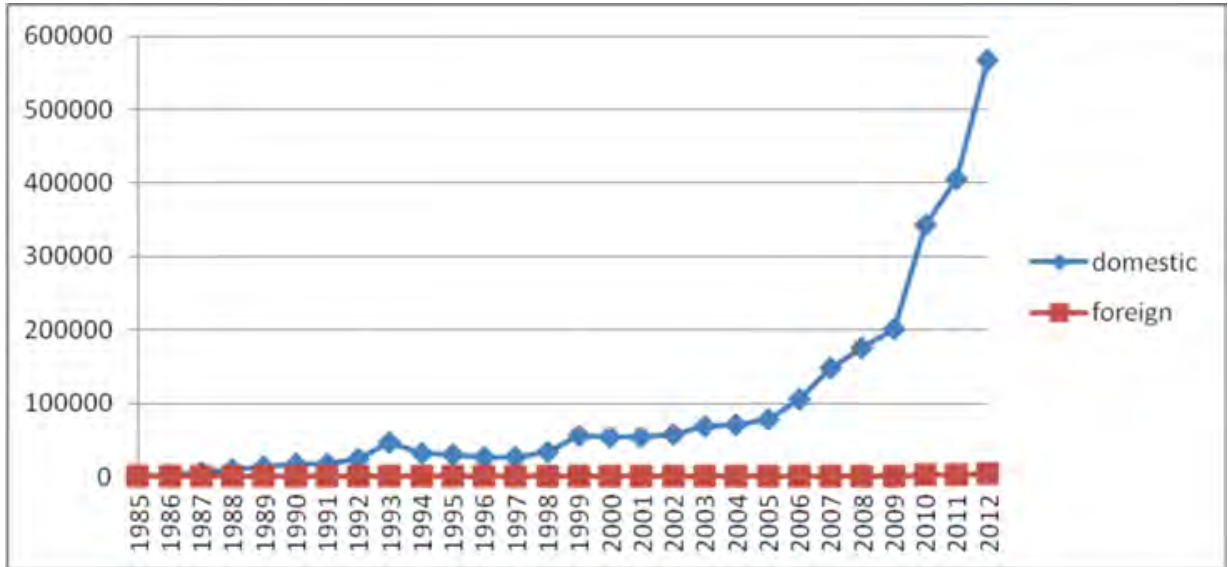

Figure 20.5 Utility Model Patents Granted Annually to Domestic and Foreign Entities, 1985-2012 


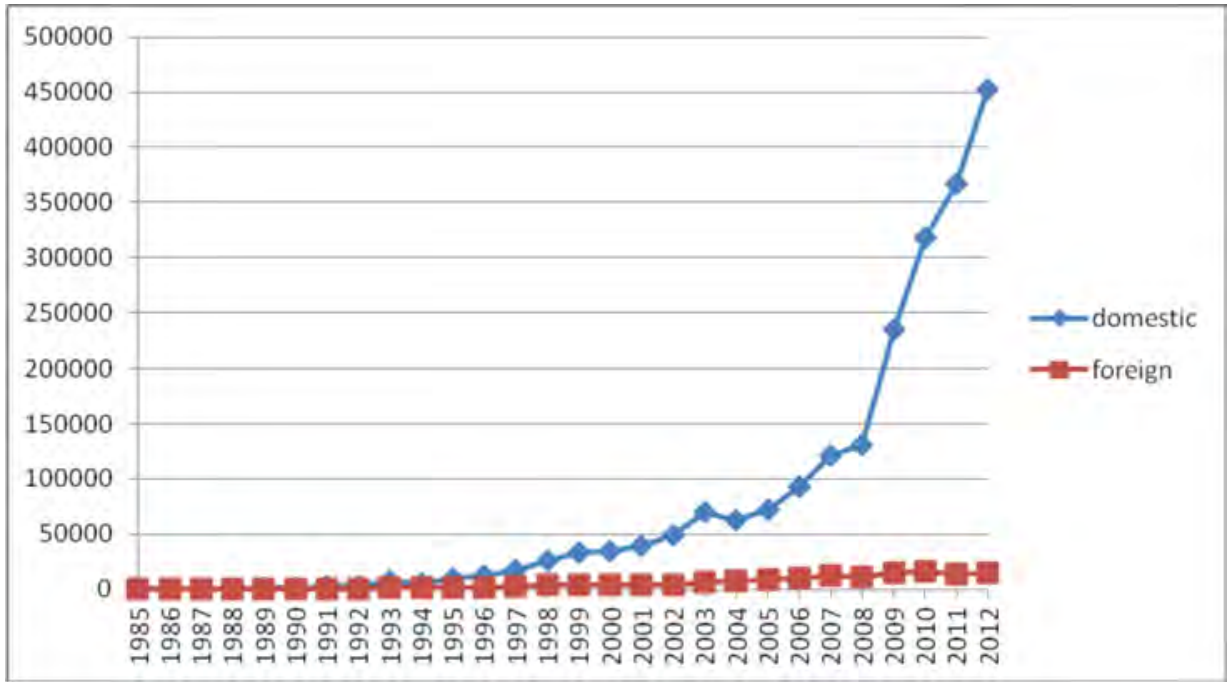

Figure 20.6 Industrial Design Patents Granted Annually to Domestic and Foreign Entities, 1985-2012

At the international level, China has also increased its international patent applications under the Patent Cooperation Treaty (PCT) in recent years, especially since the mid 2000s. Figure 20.7 shows the trend of PCT applications for the top-five origins - namely the United States, Japan, Germany, China and Republic of Korea - from 1990 to 2012. According to recently released data from the World Intellectual Property Organisation (WIPO), China has surpassed Germany and ranked third in the world in the number of PCT applications by the end of 2013.

An interesting question is whether the rapid increase of patenting activities by Chinese entities in China and abroad truly reflects the country's innovation capabilities. The answer is not clear. On the one hand, patent statistics do have some advantages as a measure of innovation especially in the lack of good measures of technological change. Patent statistics are available, by definition related to inventiveness, and based on what appears to be an objective and only slowly changing standard. As noticed by Griliches (1990), in spite of many difficulties and reservations, patent data remain a unique resource for the study of innovation and technical change in both micro and macro-economic activities. 


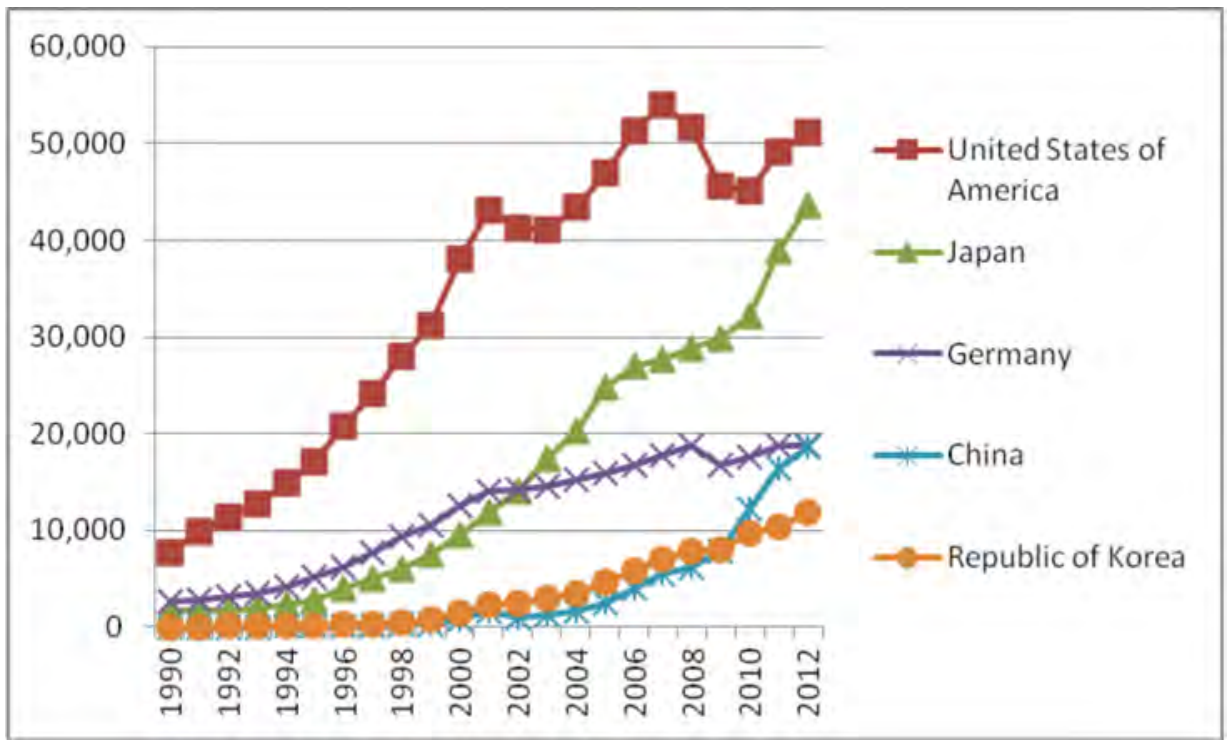

Figure 20.7 Trend in PCT Applications for the Top-Five Origins, 1990-2012

On the other hand, there is reason to question whether the number of patent applications or grants is a good indicator of innovation. While, by definition, patents (invention) need to be novel, inventive in technology and useful in industrial application, innovation is not limited to patented technology. Many patents have never been used in industry, and some are only invented to obtain government subsidies or intimidate competitors. Innovation refers to the introduction or application of new ideas, things or methods, whereas patents (or invention) refer more directly to the creation of them. Therefore, if a patent (or an invention) is not put into use, it can hardly be called an innovation. According to $\mathrm{Xu}$ and Gao (2002), the patent commercialisation rate was around 10 per cent in 2000, which was far below the level of developed countriesbetween roughly 60 per cent and 80 per cent.

Second, patents vary greatly in technical and economic significance. Even in the same industry or technology subclass, patents differ greatly in value. Therefore, simple comparisons of numbers of patents do not convey much useful information related to innovation. Moreover, patent statistics are classified according to the International Patent Classification (IPC), which is based on technological categories and cannot be directly translated into industrial sectors. Although some economists (Evenson and Putnam 1988; Schmoch et al. 2003) have tried to merge patent classes with economically relevant industries or product groupings, there remain some inherent ambiguities and difficulties for example, some patents may belong to several industries depending on their usage. 
Last but not least, in recent years various government subsidies and incentives have attracted a rapid increase in patent applications in China. As noticed by Wild (2011) and Liang (2012), the combination of subsidised patent application processes plus major tax savings creates a large incentive for Chinese companies to apply for patents, but may not result in uniformly high patent quality. There are better and more ingenious ways to increase and improve innovation than setting arbitrary benchmarks for patent filings and offering tax breaks, money and in-kind rewards that outweigh the costs of filing patents. Such incentives have induced a flood of 'junk' patents. Patents may lose any relation to true innovation. Rather than equate patents with novel and useful inventions, companies and individuals will instead perceive patents as a tax break, or some other short-term financial benefit. This wastes a huge amount of social resources, including examination and administration.

\section{What can we learn from the literature on optimising the patent institution in economic development?}

\section{Optimal design of the patent institution}

The core issue in designing the patent institution is how to balance private incentives and public interests.

To tackle the trade-off between providing incentives and causing potential monopoly inherent in the patent institution, many economists try to fit the patent system with a measurable design of optimal patent length (life) and breadth (scope). Nordhaus (1969) and Scherer (1972) initiate an analysis of the optimal patent life by modelling the trade-off inherent in the patent institution - an institution that creates static losses by granting innovators temporary monopoly power in order to realise social gains by inducing greater innovative effort. According to their argument, it is better to restrict patent life in order to reduce the associated deadweight loss because usually the longer the duration of patent protection, the stronger the incentive for innovation, but also the greater the monopoly power.

Theoretically, differentiated patent protection terms are better than a unified statutory patent life for all types of technologies. In reality, however, it is impractical for any government to determine which inventions should be given longer or shorter patent life due to asymmetry of information and inherent uncertainty of invention. Thus, in the real world, patent length is almost statutorily the same: usually 20 years from the filing date for invention 
patents and 10 years for utility models and industrial designs, as regulated by the TRIPS Agreement. Although it is difficult to differentiate statutory patent life individually, an annual patent maintenance fee system was created to let patent owners themselves decide whether they would like to pay the annual patent fees in order to keep their patents valid. The annual patent fee system thus plays an important role in balancing the trade-off between private and public interests in patented technologies.

Since it is technically and practically difficult to allow different statutory patent lengths across technologies and in reality governments usually fix a finite statutory patent duration and use an annual fee system to avoid excessive monopoly power, more follow-on research is concentrated on the optimal design of patent breadth (scope). The breadth of a patent refers to the patent scope in the sense of patent law; it is determined by claims made in an application and accorded by patent examiners to a patentee, defining the boundaries between what is protected and what is not. As most technologies are based on previous innovations, patent breadth becomes extremely important in balancing the incentives for the first-generation and follow-on innovations.

There are two main opposing camps on how to balance the incentives for firstgeneration inventors of initial technologies and second-generation innovators of applied R\&D. Scotchmer (1991), Chang (1995), Green and Scotchmer (1995) and Matutes et al. (1996) argue that first-generation inventors of initial technologies should be given strong forward protection so as to overcome the inter-temporal externality that arises when second-generation improvements can be obtained by outsiders. Broad forward protection can, however, stifle second-generation products, affect the accessibility of patented knowledge embedded in the initial inventions, and thus slow the rate of innovation, as emphasised by Merges and Nelson (1994) and Heller and Eisenberg (1998).

Clearly, there are no simple conclusions about the optimal patent breadth. It is not necessarily optimal to protect the first innovation so broadly that every second-generation product infringes, nor so narrowly that a new product never infringes. In reality, an applicant usually wants to claim as much as possible, and then a patent office must decide what claims are allowable. While decisions regarding what to allow are constrained by a number of legal principles, and by the invention itself, in many cases a patent office has considerable room for discretion. Within that discretionary zone, the office must decide which claims should be admitted and which pruned or rejected.

According to the TRIPS Agreement, with some very limited exceptions, 'patents shall be available for any inventions, whether products or processes, in all fields of technology, provided that they are new, involve an inventive step and are capable of industrial application' (Clause 1 of Article 27, the TRIPS 
Agreement, 1994). Under this general requirement, however, a national patent law can be flexible in recognising what inventions can satisfy its standards for novelty, non-obviousness (an inventive step) and industrial applicability. For example, some inventions related to software or business methods are recognised as patents by the US Patent and Trademark Office (USPTO), but they may be turned down by the Chinese Patent Office, as Chinese patent examiners may interpret such inventions as lacking an inventive step according to the Chinese Patent Law. Thus, we can see that patent breadth or scope is closely related to patentability requirements. Therefore, patentability requirements are an important and operational instrument for optimal patent design at a national level; however, there is a tendency to harmonise the substantive patent laws at an international level, which will further limit the discretionary power in patent examination in each nation.

One general conclusion we can draw is that China should make its own patent institution according to its technological and economic strengths so as to address the trade-off between promoting the diffusion of knowledge and rewarding innovators. Sakakibara and Lee (2001) find that before 1988 Japan traditionally had a narrower patent scope than the United States since Japan had a comparative advantage in applied R\&D. Unfortunately, in the formation and revision of the Chinese Patent Law, economists have rarely provided advice on the design and improvement of the Chinese patent institution. Most of the early Chinese patent founders learned their patent knowledge in the 1970s and 1980s abroad, where they were taught about the positive aspects of patents in promoting invention and creation, but little was emphasised about the potential negative side of patents for the monopoly they could cause. Moreover, there seems to be a gap between the theoretical optimal patent design and real-world patent policymaking, which might have been caused particularly by a lack of communication between economic researchers and the patent community, whose members are mainly engineers and legal professionals; but it might also be due to the inability of economists to make their messages operational.

\section{The patent institution, international trade and technology transfer}

Another important role of the patent institution in the context of economic globalisation is to facilitate technology transfer. As Hayami and Godo (2005:349) assert, '[e]ffective borrowing of technologies developed in advanced economies is the key for late starters of industrialization to catch up with early starters'. Therefore, it is interesting to explore the impacts of an increasingly pro-patent policy on China's international trade and technology transfer. 
Basically, the protection strength of patents or other IPRs affects international trade flows. If a nation strengthens its patent law, it could experience higher or lower imports as foreign firms may face increasing net demand for their products due to strengthened patent protection, but they may also choose to reduce their sales in this nation's market because of their greater market power in an imitationsafe environment. Maskus and Penubarti (1995) find that strengthening patent protection has a positive impact on bilateral manufacturing imports into large developing economies, but a negative impact on small ones. Further, Fink and Primo Braga (1999) provide new evidence regarding the effects of patent protection on international trade. They confirm a positive link between patent protection and trade flows for the aggregate of non-fuel trade, but do not find a significant positive relationship between patent protection and high-technology trade flows.

Maskus (1997) summarises the predicted relationship between patent protection, FDI and technology transfer. First, FDI and technology transfer are relatively insensitive to international differences in patent protection in sectors that have old products and standardised, labour-intensive technologies because FDI is influenced more by factor costs, market size, trade costs and other location advantages than by patent policies in this setting. Second, other things being equal, FDI that represents complex but easily copied technologies is likely to increase as patent protection is strengthened. Third, to the extent that stronger patents reduce licensing costs, FDI could be displaced over time by efficient licensing. Finally, whatever the mode, the likelihood of the most advanced technologies to be transferred increases with the strength of patents.

Empirical studies provide mixed messages about the effects of patents on technology diffusion. In some models, technology is transferred through imitation by firms in developing countries. When the global patent system is strengthened by the adoption of minimum standards set in the TRIPS Agreement, imitation becomes more difficult as foreign patents are enforced. The rate of imitation declines, but contrary to what might be expected, this decline slows the global rate of innovation also: if innovative firms expect slower loss of their technological advantages, they can earn higher profits per innovation, reducing the need to engage in R\&D (Helpman 1993; Glass and Saggi 2002). This result is, however, sensitive to model assumptions and may not hold up to alternative specifications. Indeed, Lai (1998) found that product innovation and technology diffusion are strengthened under stronger patent protection if production is transferred through FDI, rather than through imitation. This result points clearly to the need for developing economies to remove impediments to inward FDI as they strengthen their patent institutions. 
Hall (2011) finds that stronger patent protection encourages FDI and technology transfer to mid-level developing countries, but that there is little clear evidence that stronger patent protection encourages indigenous innovation in least-developed countries. These conclusions seem consistent with the idea that a certain level of absorptive capacity is necessary to make use of and learn from imported technology, but that if a country has the absorptive capacity, it is more likely to receive the technology if the foreign firm from which it comes feels that its ownership rights are protected. It should be noted, however, that although IP protection is clearly considered a favourable factor for foreign investment and technology transfer, factors such as the size of the recipient economy, its expected growth and the availability of qualified personnel are all important to attract FDI and foreign technology.

China has been pushed to establish and strengthen its patent institution since the 1980s. Patent and other IP protection has been on the top of the negotiation list of developed countries doing business with China. In the late 1980s and early 1990s, the United States and some other developed countries claimed they lost billions of dollars of revenue annually due to rampant piracy and counterfeiting in China. The US Government threatened China repeatedly with economic sanctions, trade wars and non-renewal of most-favoured-nation status to protect their business. As China tried to join the World Trade Organisation (WTO), it had to meet the international minimum standards on IP protection under the TRIPS Agreement by substantially revising its IP-related laws and regulations.

Meanwhile, China gradually realised the importance of IP in stimulating innovation and facilitating trade. Weak IP enforcement is regularly cited as a major problem for companies operating in China and as a barrier that restricts the types of activities companies are willing to undertake. Strong IP protection plays a much larger role in signalling to potential investors that a particular country recognises and protects the rights of foreign firms to make strategic business decisions with few government impediments. Because IP protection has taken on increasing importance to multinational enterprises, the adoption of stronger IP regimes has become a primary device that the Chinese Government has used to indicate a shift towards a more business-friendly environment. Until now, there have been more and more foreign multinational R\&D centres established in China. From 2000 to 2010, the number of foreign-invested $\mathrm{R} \& \mathrm{D}$ centres increased from less than 200 to more than $1300 .^{2}$ Due to both 'external pushes' and 'internal pulls', China has strengthened patent and other IP protection.

2 Please refer to The Business Times (2011) 
Hu and Jefferson (2009) and Zhang (2010) confirmed that R\&D intensification in China is one of the primary driving forces of China's patent boom. They also find that the impact of FDI on patenting is large, but slightly less important than $\mathrm{R} \& \mathrm{D}$ in explaining the patent explosion. In addition, the pro-patent amendments to the Chinese Patent Law in 2000, China's entry to the WTO and the deepening of enterprise reform all partially explain the patent boom. Using data from 1995 to 2000, Cheung and Lin (2004) find that provinces with more FDI have more domestic patent applications. They attribute this to a form of spillover from foreign investment-namely, a demonstration effect on domestic enterprises.

\section{The patent institution and economic growth}

A good understanding of the two previous issues is helpful in understanding the connection between the patent institution and economic growth. The growing consensus is that strong IP regimes in developing countries could have a long-term beneficial effect on their economic growth. This favourable effect is dependent, however, on other important factors, such as improving human capital, particularly in technical skills, expanding technical infrastructure, developing efficient managerial techniques, investing in $\mathrm{R} \& \mathrm{D}$, increasing the openness and transparency of the domestic market, and encouraging international trade and investment from abroad. While sufficiently strong IP protection is helpful for promoting FDI and other forms of technology transfer, it is absolutely critical for encouraging investment in R\&D. Thus, economic development cannot be disconnected from technology transfers and the protection of patents. Strong patent protections are seen to encourage economic development by: 1) promoting domestic innovation by protecting the development of nascent technology; 2) preventing brain drain by ensuring innovators are rewarded for their effort; and 3) fostering technology transfers, such as FDI, licensing and imports.

A few studies have investigated the impact of IP protection on crosscountry economic growth. Gould and Gruben (1996) estimate a growth model on a cross-section of up to 95 countries with data averaged over the period 1960-88, including an index measuring patent protection strength created by Rapp and Rozek (1990) in their regression. They find that IP protection can have a slightly larger impact on growth in open economies. Therefore, trade liberalisation in combination with stronger patent protection enhances growth because it improves the competitive nature of markets and increases access to foreign technologies.

Thompson and Rushing (1996) employ a switching regression model to examine whether increased patent protection is more beneficial once a country has reached a particular level of development, as measured by initial 
GDP per capita. Their results indicate a break in the data, at an initial level of US\$3400 (1980 prices). For countries below this no relationship between patent protection and growth is found; above it, there is a positive and significant relationship. Thompson and Rushing (1999) extend this model and once again suggest that patent protection has a positive and significant impact upon TFP only for the most advanced countries, with insignificant coefficients found for the full sample and the sample of developing countries.

Park and Ginarte (1997) create an index of patent rights for 110 countries for the period 1960-90. The index is used to examine what factors or characteristics of economies determine how strongly patent rights will be protected. The evidence indicates that more developed economies tend to provide stronger protection; but the underlying factors that influence patent protection levels are the country's level of R\&D activity, the market environment and international integration, which are correlated with its level of development. The R\&D activity influences patent protection levels after a nation's research sector reaches a critical size. An implication is that to raise patent protection levels in weakly protecting countries, it is important to foster a significant research base in those countries and thereby create incentives for protecting patent rights.

Maskus and McDaniel (1999) investigate empirically how the Japanese patent institution has affected postwar growth in Japanese total factor productivity (TFP). The postwar Japanese patent institution before 1988 was recognised as a mechanism for promoting technological catch-up and diffusion through incremental innovation. Given certain patent procedures, such as pregrant disclosure, single-claim requirement, first-to-file and lengthy pending periods, the Japanese patent institution has enabled a channel of technology transfer through the application process. Maskus and McDaniel (1999) find that technology diffusion through utility-model applications had a positive impact on Japan's postwar productivity growth.

There have been few empirical papers dealing with the impact of patents on economic growth in China. Zhao and Liu (2011) find that China's domestic patents had a positive impact on China's TFP from 1988 to 2009, and the impact of invention patents on TFP is much larger than utility-model patents and design patents in 1999-2009. However, before 1999, invention patents seemed to have had little impact on TFP. After 1999, the technological progress reflected by the increase of invention patents in China seemed to play an increasingly important role in economic growth. 


\section{Conclusions and implications}

The above overview of the patent institution from past economic studies of patents has underlined a series of practical issues that deserve policymakers' attention in China and also in developing countries.

First, patent protection is a double-edged sword, with both a positive and a negative side. Patents are usually effective in stimulating inventions, encouraging disclosure of new technologies and facilitating market transactions for new technologies. On the other side, they can also generate costs to society partially due to the potential monopoly and barriers to free use of the patented technologies. Competitive rents, in the absence of patent protection, might compensate innovators in certain circumstances. For instance, first-mover advantages arising from seizing the market are important and the cost of imitation is high; patents may not be necessary to encourage such innovation. An optimal patent institution should establish a good balance.

Second, patentability requirements, such as novelty, non-obviousness and industrial applicability, are important instruments to avoid the granting of unqualified patents that increase the social cost of the patent institution. Moreover, strict application of such principles in patent examination is also an effective measure to prevent broad patent protection scope that could deter further innovation and improvement.

Third, in the current globalisation context, such as TRIPS and other international patent agreements, a nation often has limited leverage in making its own patent law and policy - for instance, the statutory patent life should be at least 20 years and patent protection should cover almost all technologies, which may not be in the interests of most developing countries. It is important for developing countries to realise this point and cooperate with each other to seek their interests in international negotiations on IP and patent protection.

Fourth, empirical studies seem to support the theoretical importance of the patent institution in promoting trade, attracting FDI and facilitating technology transfer. However, the net impact on technology transfer to developing countries under the current international patent framework is still ambiguous. It seems stronger patents encourage technology transfer only to mid-level developing countries, but they have little effect on technology transfer to the lowest-income countries.

Last but not least, cross-country analyses seem to show that IP or patent protection has a positive and significant contribution to the economic growth in high-income countries, while for low-income and middle-income countries, the net impact is ambiguous. 
The relationship between patents and economic development in developing countries is more complex than that observed in developed countries. In the short term, developing countries may be disadvantaged in filing competitive patents; and developed countries may take advantage of the international harmonised patent institution to secure their innovation and market power in developing countries. In the long term, it depends on developing countries' domestic enterprises whether they can learn fast and compete with multinational companies under a framework that favours of stronger technological innovators.

\section{References}

Arrow, K. (1962), 'Economic welfare and the allocation of resources for invention', in The Rate and Direction of Inventive Activity: Economic and Social Factors, pp. 609-26, Cambridge, Mass.: National Bureau of Economic Research.

Bentham, J. (1839), The Works of Jeremy Bentham, J. Bowring ed., The Online Library of Liberty. Available from < http://oll.libertyfund.org/title/1922>.

Boldrin, M. and Levine, D. (2002), 'The case against intellectual property', American Economic Review 92(2):209-12.

Chang, H. (1995), 'Patent scope, antitrust policy, and cumulative innovation', The RAND Journal of Economics 26(1):34-57.

Cheung, K.-Y. and Lin, P. (2004), 'Spillover effects of FDI on innovation in China: evidence from provincial data', China Economic Review 15(1):25-44.

Colombo, M. G. and Delmastro, M. (2002), 'How effective are technology incubators? Evidence from Italy', Research Policy 31:1103-22.

Drahos, P. (1995), 'Information feudalism in the information society', The Information Society 11:209-22.

Drahos, P. (ed.) (1999), Intellectual Property, Aldershot, UK: Ashgate.

Evenson, R. and Putnam, J. (1988), The Yale-Canada patent flow concordance, Economic Growth Centre Working Paper, Yale University, New Haven, Conn.

Fink, C. and Primo Braga, C. A. (1999), How stronger protection of intellectual property rights affects international trade flows, Working Paper No. 2051, The World Bank, Washington, DC.

Glass, A. J. and Saggi, K. (2002), 'Intellectual property rights and foreign direct investment', Journal of International Economics 56(2):387-410. 
Gould, D. M. and Gruben, W. C. (1996), 'The role of intellectual property rights in economic growth', Journal of Economic Development 48:323-50.

Green, J. and Scotchmer, S. (1995), 'On the division of profits in sequential innovation', The RAND Journal of Economics 26(1):20-33.

Griliches, Z. (1990), 'Patent statistics as economic indicators: a survey', Journal of Economic Literature 28(4):1661-707.

Hall, B. H. (2011), 'The internationalization of R\&D', in A. Sydor (ed.), Global Value Chains: Impacts and Implications, pp. 179-210, Ottawa: Foreign Affairs and International Trade Canada, Government of Canada.

Hayami, Y. and Godo, Y. (2005), Development Economics: From the Poverty to the Wealth of Nations, New York: Oxford University Press.

Heller, M. and Eisenberg, R. (1998), 'Can patents deter innovation? The anticommons in biomedical research', Science 280:698-701.

Helpman, E. (1993), 'Innovation, imitation, and intellectual property rights', Econometrica 61(6):1247-80.

Hu, A. G. and Jefferson, G. H. 2009, 'A great wall of patents: what is behind China's recent patent explosion', Journal of Development Economics 90:57-68.

Hulme, E. W. (1896), 'The history of the patent institution under the prerogative and at common law', Law Quarterly Review 46:141-54.

Idris, K. (2003), Intellectual Property - A Powerful Tool for Economic Growth, Geneva: World Intellectual Property Organisation.

Lai, E. L. (1998), 'International intellectual property rights protection and the rate of product innovation', Journal of Development Economics 55(1):133-53.

Liang, M. (2012), 'Chinese patent quality: running the numbers and possible remedies', The John Marshall Review of Intellectual Property Law 11:478-512.

Maddison, A. (1999), 'Poor until 1820', Wall Street Journal [Europe], 11 January 1999.

Martin, S. and Scott, J. T. (2000), 'The nature of innovation market failure and the design of public support for private innovation', Research Policy 29(4-5):437-47.

Maskus, K. E. (1997), The role of intellectual property rights in encouraging foreign direct investment and technology transfer, Prepared for the PublicPrivate Initiatives after TRIPS: Designing a Global Agenda Conference, Brussels. 
Maskus, K. E. and McDaniel, C. (1999), 'Impact of the Japanese patent system on productivity growth', Japan and the World Economy 11(4):11 557-74.

Maskus, K. E. and Penubarti, M. (1995), 'How trade-related are intellectual property rights?', Journal of International Economics 39:227-48.

Matutes, C., Regibeau, P. and Rockett, K. (1996), 'Optimal patent design and the diffusion of innovations', The RAND Journal of Economics 27(1):60-83.

Merges, R. and Nelson, R. (1994), ‘On limiting or encouraging rivalry in technical progress: the effect of patent scope decisions', Journal of Economic Behaviour and Organization 25:1-24.

Moir, H. V. J. (2008), What are the costs and benefits of patent systems?, Centre for Governance of Knowledge and Development Working Paper, The Australian National University, Canberra.

Naik, G. (2010), 'China surpasses Japan in R\&D as powers shift', The Wall Street Journal. Available from <http://online.wsj.com/article/SB100014240527487 03734204576019713917682354.html>.

Nordhaus, W. (1969), Invention, Growth and Welfare: A Theoretical Treatment of Technological Change, Cambridge, Mass.: MIT Press.

Park, W. G. and Ginarte, J. C. (1997), 'Determinants of patent rights: a crossnational study', Research Policy 26:283-301.

Pigou, A. C. (1920), The Economics of Welfare, 4th edn, The Online Library of Liberty. Available from <http://oll.libertyfund.org/Ebooks/Pigou_0316. pdf $>$.

Posner, R. (2012), 'Why there are too many patents in America', The Atlantic, 12 July 2012. Available from <http:/www.theatlantic.com/business/ archive/2012/07/why-there-are-too-many-patents-in-america/259725/>.

Rapp, R. T. and Rozek, R. P. (1990), 'Benefits and costs of intellectual property protection in developing countries', Journal of World Trade 24(5):75-102.

Sakakibara, M. and Lee, B. (2001), 'Do stronger patents induce more innovation? Evidence from the 1988 Japanese patent law reforms', The RAND Journal of Economics 32(1):77-100.

Scherer, F. M. 1972, 'Nordhaus' theory of optimal patent life: a geometric reinterpretation', American Economic Review 62(3):422-7. 
Schmoch, U., Laville, F., Patel, P. and Frietsch, R. (2003), Linking technology areas to industrial sectors: final report to the European Commission, DG Research. Available from < ftp://ftp.cordis.europa.eu/pub/indicators/docs/ind_report_ isi_ost_spru.pdf $>$.

Scotchmer, S. (1991), 'Standing on the shoulders of giants: cumulative research and the patent law', Journal of Economic Perspective 5(1):29-41.

Smith, A. (1776), Wealth of Nations, London: W. Strahan \& T. Cadell.

Taussig, F. W. (1915), Inventors and money makers. Available from <http://www. unz.org/Pub/TaussigFW-1915>.

The Business Times (2011), 'World to gain from an innovative China', The Business Times, 11 July 2011. Available from <http://www.businesschina.org.sg/ en.php/resources/news/317/1>.

Thompson, M. and Rushing, F. (1996), 'An empirical analysis of the impact of patent protection on economic growth', Journal of Economic Development 21(2):61-79.

Thompson, M. and Rushing, F. (1999), 'An empirical analysis of the impact of patent protection on economic growth: an extension', Journal of Economic Development 24(1):67-76.

United Kingdom Commission on Intellectual Property Rights (UK Commission on IPR) (2002), Integrating Intellectual Property Rights and Development Policy. Available from < http://www.iprcommission.org/graphic/documents/ final_report.htm $>$.

Wild, J. (2011), 'Quality is China's biggest patent challenge - updated', IAM Magazine. Available from <http:/www.iam-magazine.com/blog/Detail. aspx?g=e81c5421-bccc-4eb5-9895-f347443cf73e>.

$\mathrm{Xu}, \mathrm{W}$. and Gao, Y. (2002), 'Venture investment system and counter measures in the process of hi-tech achievements' transformation', Journal of Technology College Education 21(4).

Zhang, H. (2010), 'What is behind the recent surge in patenting in China?', International Journal of Business and Management 5(10):83-91.

Zhao, Y. and Liu, S. (2011), Effect of China's domestic patents on total factor productivity: 1988-2009. Available from <ftp:/ftp.zew.de/pub/zew-docs/ veranstaltungen/innovationpatenting2011/papers/Liu.pdf $>$. 
This text taken from Deepening reform for China's long-term growth and development, edited by Ligang Song, Ross Garnaut, Cai Fang, published July 2014 by ANU Press, The Australian National University, Canberra, Australia. 